\title{
EFEKTIVITAS MODEL NOVICK TERHADAP KETERAMPILAN MENULIS TEKS DRAMA PADA SISWA KELAS VIII SMP SWASTA ANGKASA LANUD SOEWONDO MEDAN TAHUN PEMBELAJARAN 2018/2019
}

\author{
Oleh \\ Bobby Tambunan (tambunanbobby04@gmail.com) \\ Salmah Naelofaria (snaelofaria@gmail.com) \\ Universitas Negeri Medan
}

\begin{abstract}
ABSTRAK
Penelitian ini mengkaji tentang keterampilan menulis teks drama dengan model Novick. Penelitian ini bertujuan untuk mengetahui keefektifan model Novick terhadap keterampilan menulis teks drama pada siswa kelas VIII SMP Swasta Angkasa Lanud Soewondo Medan tahun pembelajaran 2018/2019. Populasi dalam penelitian ini adalah seluruh siswa kelas VIII yang terdiri atas 3 kelas yang berjumlah 61 siswa. Sampel penelitian ini adalah kelas VIII A yang berjumlah 20 siswa. Penelitian ini menggunakan metode eksperimen. Desain penelitian yang digunakan one group pretest posttest design. Berdasarkan pengolahan data diperoleh hasil pretest dengan rata-rata $=54,15$ dan standar deviasi $=15,28$. Sedangkan hasil posttest dengan rata-rata $=83,61$ dan standar deviasi $=8,73$. Dari uji data pretest dan posttest diketahui bahwa kedua data tersebut berdistribusi normal. Data pretest diperoleh $\mathrm{L}_{\text {hitung }}<\mathrm{L}_{\text {tabel }}(0,1889<0,190)$ dan data posttest diperoleh $\mathrm{L}_{\text {hitung }}<\mathrm{L}_{\text {tabel }}(0,1242<0,190)$. Sedangkan dari uji homogenitas diperoleh bahwa sampel penelitian ini berasal dari kelompok yang homogen yaitu $F_{\text {hitung }}<F_{\text {tabel }}(1,75<2,12)$. Setelah uji normalitas dan homogenitas dilakukan, diperoleh $t_{o}=7,47$. Selanjutnya $t_{o}$ Dikonsultasikan dengan $\mathrm{t}$ tabel pada taraf signifikan 5\% dengan $\mathrm{df}=19$, maka diperoleh sebesar 2,09. Oleh karena $t_{o}$ Yang diperoleh lebih besar dar $t_{\text {tabel }}$ Yaitu 7,47 > 2,09, maka $H_{a}$ Diterima.Hal ini membuktikan bahwa model Novick efektif digunakan terhadap keterampilan menulis teks drama pada siswa kelas VIII SMP Swasta Angkasa Lanud Soewondo Medan tahun pembelajaran 2018/2019.
\end{abstract}

\section{Kata Kunci : Model Novick, Keterampilan Menulis Teks Drama}

\section{PENDAHULUAN}

Keterampilan menulis merupakan sebuah kegiatan menuangkan pikiran, gagasan, dan perasaan seseorang yang diungkapkan dalam bahasa tulis. Keterampilan ini didukung oleh kemampuan memadukan gagasan atau ide ke dalam bentuk struktur kalimat efektif. Kekayaan kosa kata dan kekohesifan antar wacana tulis merupakan kunci utama dalam potensi hasil tulisan. Kemudian bahasa tulis ini diharapkan dapat 
dipahami oleh pembaca. Keterampilan menulis dapat ditingkatkan melalui menulis teks drama.

Drama merupakan salah satu jenis karya sastra yang ditulis dalam bentuk dialog yang didasarkan atas konflik batin dan dipentaskan. Menulis teks drama sebagai salah satu bagian dari menulis sastra yang dapat dimanfaatkan untuk meningkatkan keterampilan menulis siswa. Oleh karena itu, menulis teks drama sebagai salah satu keterampilan bersastra perlu mendapat perhatian yang serius dalam pengajaran bahasa dan sastra Indonesia.

Standar kompetensi mata pelajaran bahasa dan sastra Indonesia untuk jenjang SMP/MTs pada kelas VIII KD 4.16 kurikulum 2013 revisi, salah satunya adalah siswa mampu menyajikan drama dalam bentuk teks. Berkaitan dengan hal tersebut, keterampilan menulis teks drama pada siswa SMP kelas VIII harus sesuai dengan indikator-indikator yang harus dicapai. Tujuan akhir dari KD ini adalah siswa harus mampu menulis teks drama. Kemampuan menulis drama pda siswa merupakan hal yang mampu menunjukkan perpaduan imajinasi yang terpadu pada daya pikir masing-masing siswa tersebut. Teks drama yang ditulis didasarkan pada pengalaman ataupun ide yang pernah mereka imajinasikan sendiri. Kemampuan mengelola teks ke dalam naskah drama merupakan kompetensi menulis yang diikuti dengan perpaduan struktur dan daya pikir. Oleh sebab itu diperlukan suasana yang aktif dan sinergis dalam kelas demi mendukung ketercapaian tujuan pembelajaran.

Berdasarkan hasil pengamatan di SMP Swasta Angkasa Lanud Soewondo Medan, ditemukan data bahwa siswa pada sekolah ini kurang mempunyai keterampilan menulis teks yang baik sehingga proses pembelajaran berjalan kurang baik dan terarah sesuai kompetensi capaian yang diharapkan. Dalam pembelajaran bahasa Indonesia kelas VIII, KKM yang harus diperoleh adalah 75. Sementara berdasarkan data dan fakta yang diperoleh, siswa yang lulus pada tes kemampuan menulis teks drama hanya 2 orang dari 20 siswa. Data tersebut diperoleh dari data-data tes kemampuan siswa dalam menulis teks drama dan hasil wawancara terhadap guru mata pelajaran bahasa Indonesia. Sesuai dengan KD 4.16 siswa mampu menyajikan drama dalam bentuk teks, maka keterampilan menulis teks drama siswa perlu ditingkatkan.

Pada pembelajaran bahasa Indonesia, kendala yang dapat menghambat proses pembelajaran salah satunya adalah mengenai kondisi kelas yang tidak kondusif yang 
menyebabkan siswa tidak fokus pada saat proses pembelajaran. Padahal, lingkungan fisik dalam ruang kelas dapat mejadikan belajar aktif. Tidak ada satupun bentuk ruang kelas yang ideal, namun ada beberapa pilihan yang dapat diambil sebagai variasi. Dekorasi interior kelas harus dirancang yang meungkinkan anak belajar aktif, yakni yang menyenangkan dan menantang.

Dalam berbagai literatur tulisan tentang tata kelola ruang kelas kita banyak menjumpai tata letak ruang kelas sehingga proses belajar mengajar dapat berlangsung dengan baik. Namun, bagaiamana pun hal tersebut ditentukan oleh guru itu sendiri. Seorang guru harus bisa menata ruangan kelasnya dengan baik sesuai dengan kondisi dan suasana belajar yang diinginkan. Kreatifitas seorang guru sangat diperlukan, selain memperhatikan bagaimana cara mengajar yang baik dan menyenangkan, seorang guru pun harus pandai memperhatikan keadaan ruangan kelasnya. Selain itu pula, jumlah peserta didik dalam satu ruangan harus diperhatikan. jangan sampai dalam satu ruangan menumpuk terlalu banyak murid. Sehingga guru dapat dengan mudah mengawasi peserta didiknya,

Berkaitan dengan pengamatan pada saat observasi di SMP S Angkasa Lanud Soewondo Medan, kondisi kelas pada sekolah ini tidaklah kondusif. Data ini diperkuat melalui angket tentang kondisi kelas dengan sampel penelitian 20 siswa. Melalui analisis yang dilakukan pada angket tersebut juga menyatakan bahwa guru tidak menggunakan metode yang bervariasi saat proses pembelajaran yang mengakibatkan kebosanan pada siswa. Jika terus dibiarkan, maka tidak hanya kemampuan kognitif dalam proses pembelajaran saja yang menurun, bahkan kemampuan lainnya seperti keaktifan dan sikap akan menurun.

Berkaitan dengan hal tersebut, penelitian yang dilakukan oleh Petrus Danang Mustika Wijaya yang berjudul "Peningkatan Kemampuan Menulis Teks Drama Menggunakan Media Video Klip pada Siswa Kelas XI IPA 2 SMA N 1 Prambanan Klaten Tahun Ajaran 2015/2016" bahwa siswa yang tuntas dalam pembelajaran menulis teks drama hanya 8 siswa atau $25 \%$ dari 32 siswa. Hal ini menunjukkan bahwa keterampilan siswa dalam menulis teks drama pada siswa masih rendah. 
Pembelajaran akan semakin efektif dan efisien jika proses pembelajaran diselaraskan dengan model-model pembelajaran yang ada dapat menarik perhatian siswa pada saat proses pembelajarannya sesuai materi pembelajaran. Model-model pembelajaran diharapkan dapat bervariasi supaya siswa tidak mudah mengalami kebosanan terhadap proses pembelajaran. Salah satu model pembelajaran yang mendorong siswa untuk meningkatkan hasil belajar mereka adalah model pembelajaran konstruktivisme. Konstruktivisme adalah menemukan informasi pengetahuan dan kompetensi sendiri. Setiap kegiatan pembelajaran banyak model atau metode pembelajaran yang digunakan. Tetapi penggunaan model harus sesuai dengan keadaan belajar siswa dan materi yang disampaikan dalam suatu kegiatan pembelajaran. Salah satu model pembelajaran konstruktivisme adalah model pembelajaran Novick.

Model pembelajaran Novick adalah salah satu model pembelajaran yang berawal dari konsep belajar sebagai perubahan konseptual yang dikembangkan dari pendekatan konstruktivisme (Sulaiman, 2012:10). Kegiatan pembelajaran menggunakan model Novick ini sangat berkaitan dengan kehidupan siswa dalam sehari-harinya. Dengan model ini, siswa akan lebih percaya diri dan dapat dengan mudah memahami konsep menulis teks drama dan mengaplikasikannya. Pengetahuan yang diperoleh peserta didik akan teringat lebih lama karena pengetahuan tersebut diperoleh dengan cara pengkontruksian.

Berdasarkan uraian diatas, maka permasalahannya adalah apakah model Novick efektif terhadap keterampilan menulis teks drama pada siswa kelas VIII SMP Swasta Angkasa Lanud Soewondo Medan tahun pembelajaran 2018/2019.

\section{METODE}

Metode yang digunakan dalam penelitian ini dalah metode eksperimen dengan desain One group Pretest Posttest Design (Sugiyono 2012:111). Model One Group Pre-test and Post-test Design merupakan eksperimen yang dilaksanakan pada satu kelompok saja tanpa pembanding.

\section{HASIL DAN PEMBAHASAN PENELITIAN}

\section{A. Hasil Penelitian}


Data nilai yang diperoleh dari hasil tes awal menulis teks drama siswa kelas VIII A SMP Swasta Angkasa Lanud Soewondo Medan adalah sebagai berikut.

Tabel 1

Identifikasi Kecenderungan Hasil Keterampilan Menulis Teks Drama Siswa sebelum Menggunakan Model Novick (Pretest)

\begin{tabular}{c|c|c|c}
\hline Interval & F. Absolut & F. Relatif & Kategori \\
\hline $85-100$ & 2 & $10 \%$ & Sangat Baik \\
$70-84$ & 0 & $0 \%$ & Baik \\
$60-69$ & 4 & $20 \%$ & Cukup \\
$50-59$ & 5 & $25 \%$ & Kurang \\
$0-49$ & 9 & $45 \%$ & Sangat Kurang \\
\hline Jumlah & 20 & $100 \%$ & \\
\hline
\end{tabular}

Berdasarkan tabel di atas, maka dapat diketahui bahwa keterampilan menulis teks drama siswa sebelum menggunakan model Novick yang termasuk kategori sangat baik sebanyak 2 siswa atau 10\%, kategori baik tidak ada atau 0\%, kategori cukup sebanyak 4 siswa atau 20\%, kategori kurang sebanyak 5 siswa atau 25\%, dan kategori sangat kurang sebanyak 9 siswa atau 45\%. Identifikasi hasil keterampilan menulis teks drama siswa sebelum menggunakan model Novick yang paling banyak adalah sangat kurang.

Data nilai yang diperoleh dari hasil tes akhir menulis teks drama siswa kelas VIII A SMP Swasta Angkasa Lanud Soewondo Medan adalah sebagai berikut.

Tabel 2

Identifikasi Kecenderungan Hasil Keterampilan Menulis Teks Drama Siswa setelah Menggunakan Model Novick (Posttest)

\begin{tabular}{c|c|c|c}
\hline Interval & F. Absolut & F. Relatif & Kategori \\
\hline $85-100$ & 10 & $50 \%$ & Sangat Baik \\
$70-84$ & 9 & $45 \%$ & Baik \\
$60-69$ & 1 & $5 \%$ & Cukup \\
$50-59$ & 0 & $0 \%$ & Kurang \\
\hline $0-49$ & 0 & $0 \%$ & Sangat Kurang \\
\hline Jumlah & 20 & $100 \%$ & \\
\hline
\end{tabular}


Berdasarkan tabel di atas, maka dapat diketahui bahwa keterampilan menulis teks drama siswa setelah menggunakan model Novick yang termasuk kategori sangat baik sebanyak 10 siswa atau 50\%, kategori baik sebanyak 9 siswa atau 45\%, kategori cukup hanya 1 siswa atau 5\%, kategori kurang tidak ada atau 0\%, dan kategori sangat kurang juga tidak ada atau 0\%. Identifikasi hasil keterampilan menulis teks drama siswa setelah menggunakan model Novick yang paling banyak adalah kategori sangat baik.

\section{B. Pembahasan Penelitian}

\section{Model Pembelajaran Novick}

Model pembelajaran Novick merupakan model pembelajaran yang didasarkan pada pandangan kontruktivisme. Model pembelajaran Novick bertujuan untuk mengkontruksi pengetahuan peserta didik (Sulaiman, 2012:10). Gagasan utama dari model pembelajaran ini adalah proses perubahan konseptual dari pengetahuan awal siswa pada proses pembelajaran.

Kelebihan yang terdapat dalam model Novick menurut Diyanti (dalam Fitriana, 2018:5) sebagai berikut.

a. Setiap fasenya memfasilitasi guru dan peserta didik untuk melakukan pembelajaran dengan sistem perubahan konseptual.

b.Pengetahuan yang diperoleh peserta didik akan teringat lebih lama karena pengetahuan tersebut diperoleh dengan cara pengkontruksian.

c. Proses belajar peserta didik menjadi lebih bermakna.

Sedangkan, Kelemahan yang terdapat dalam model Novick menurut Diyanti (dalam Fitriana, 2018:6) sebagai berikut.

a. Membutuhkan waktu yang lama. Kurangnya waktu yang dapat memberikan dampak negatif yang menimbulkan kekurangan yang begitu relefan dalam proses belajar.

b. Mengharuskan menyiapkan bahan ajar.

c. Kurangnya refleksi yang diberikan oleh guru.

\section{Pengertian Keterampilan Menulis}

Keterampilan menulis adalah salah satu keterampilan berbahasa yang produktif dan ekspresif yang dipergunakan untuk berkomunikasi secara tidak langsung dan tidak secara tatap muka dengan pihak lain (Tarigan 2008 : 3). Ketepatan pengungkapan 
gagasan harus didukung dengan ketepatan bahasa yang digunakan, kosakata dan gramatikal dan penggunaan ejaan. Menurut Saleh Abbas (2006: 127-137), upaya yang dapat dilakukan guru agar siswa senang menulis adalah dengan memberi kebebasan kepada siswa untuk menulis apa yang disenanginya sesuai dengan tema pembelajaran yang akan dilaksanakan.

Menulis cerita dalam bentuk karangan narasi misalnya dapat dilaksanakan dengan menggunakan bantuan media berupa gambar seri. Dalam pembelajaran keterampilan menulis ini guru harus menciptakan kondisi pembelajaran yang kondusif. Di samping itu guru juga harus melakukan penilaian proses yang bertujuan untuk mengetahui perkembangan belajar siswa, kesulitan yang dialami dan pola strategi belajar yang tepat.

\section{Pengertian Teks Drama}

Menurut Pratiwi (2014: 14) menyatakan bahwa kisah kehidupan manusia dalam teks drama dikembangkan dalam wujud dialog. Dialog dalam teks menggambarkan nasib, watak, konflik antar tokoh. Teks drama adalah karya sastra yang bersifat fiksi yang isinya berdasarkan kisah kehidupan yang dibentuk dalam wujud dialog. Teks drama berupa kesatuan teks tentang kisah-kisah atau cerita tentang kehidupan yang mempunyai dialog atau percakapan, tokoh-tokoh, watak, nasib yang dilakonkan. Teks drama ini dasar dari sebuah pertunjukan yang digunakan sebagai aktifitas yang akan dilakukan di atas sebuah panggung sebagai sebuah tontonan.

Istilah drama juga dikenal berasal dari kata drama (Perancis) yang digunakan untuk menjelaskan lakon-lakon tentang kehidupan kelas menengah. Drama adalah salah satu bentuk seni yang bercerita melalui percakapan dan action tokoh-tokohnya. Percakapan atau dialog itu sendiri bisa diartikan sebagai action. Kata kunci drama adalah gerak. Setiap drama akan mengandalkan gerak sebagai ciri khusus drama. Kata kunci ini yang membedakan dengan puisi dan prosa fiksi

\section{Jenis-jenis Teks Drama}

Jenis-jenis dari teks drama ditentukan dari isi yang terkandung di dalamnya. Ada 4 pembagian jenis-jenis teks drama yang dikemukakan oleh Kosasih (2017:245) sebagai berikut. 
1. Tragedi

Drama yang memunculkan kisah yang sangat menyedihkan yang dialami seorang insan yang mulia, kaum bangsawan, yang mempertaruhkan dirinya menentang rintangan-rintangan yang tidak seimbang dengan kekuatannya.

Ciri-cirinya:

a) Menampilkan kisah sedih.

b) Cerita bersifat serius.

c) Memunculkan rasa kasihan dan ketakutan.

d) Menampilkan tokoh yang bersifat kepahlawanan.

2. Komedi

Komedi mempunyai ciri-ciri sebagai berikut.

a) Menampilkan cerita-cerita ringan.

b) Meunculkan kisah serius namun dengan perlakuan nada yang ringan.

c) Mengenai peristiwa-peristiwa yang kemungkinan terjadi

d) Kelucuan muncul dari tokoh dan bukan dari situasi.

e) Gelak tawa yang ditimbulkan bersifat "bijaksana".

f)

3. Melodrama

Melodrama mempunyai ciri-ciri sebagai berikut.

a) Mengetengahkan serta menampilkan kisah yang serius.

b) Banyak memunculkan kejadian yang bersifat kebetulan.

c) Memunculkan rasa kasihan yang sifatnya sentimental.

4. Farce

Farce mempunyai ciri-ciri sebagai berikut.

a) Menimbulkan kelucuan yang tidak karuan.

b) Bersifat episodik, memerlukan kepercayaan yang sesaat.

c) Kelucuan-kelucuan muncul dari situasi, bukan dari tokoh.

\section{Unsur-unsur Teks Drama}

Setiap teks mempunyai unsur yang terkandung di dalamnya. Menurut Nurgiyantoro (dalam Ambarita, 2012:10), unsur-unsur teks drama terdiri atas:

1. Tema 
Tema adalah pikiran utama atau gagasan pokok yang mendasari adanya suatu cerita dan harus dikembangkan sedemikian rupa sehingga menghasilkan suatu cerita yang menarik.

2. Dialog

Dialog adalah ciri khas dalam teks drama berupa percakapan tokoh yang bersifat komunikatif serta menunjang gerak laku tokoh dalam sebuah drama. Dialog juga harus berkembang mengikuti suasana konflik dalam tahap-tahap plot tokoh drama.

3. Perwatakan

Perwatakan adalah pelukisan sikap dan sifat seorang tokoh untuk diwujudkan oleh pemain yang memerankan tokoh itu.

4. Latar

Latar atau setting adalah tempat terjadinya peristiwa dalam cerita yang meliputi tempat, suasana, dan waktu. Ketiga unsur tersebut saling memengaruhi dan tidak dapat dipisahkan.

5. Alur atau jalan cerita

Plot atau alur adalah rangkaian jalannya suatu peristiwa atau kejadian dalam cerita yang berkembang secara bertahap dan memiliki dalam enam tahap, yaitu eksposisi, konflik, komplikasi, krisis (klimaks), dan resolusi.

6. Amanat

Amanat adalah pesan yang ingin disampaikan pengarang dan akan memberikan manfaat kepada pembaca atau penonton.

\section{SIMPULAN DAN SARAN}

Berdasarkan hasil analisis yang telah dilakukan dalam penelitian ini, maka dapat disimpulkan bahwa model Novick efektif digunakan terhadap keterampilan menulis teks drama pada siswa kelas VIII SMP Swasta Angkasa Lanud Soewondo Medan tahun pembelajaran 2018/2019. Penelitian ini mempunyai populasi seluruh siswa kelas VIII SMP Swasta Angkasa Lanud Soewondo Medan dengan sampel penelitian 20 siswa. Penelitian ini menunjukkan hasil rata-rata keterampilan menulis teks drama siswa sebelum menggunakan model Novick (pretest) adalah 54,15 yang termasuk kategori sangat kurang. Berbeda dengan nilai rata-rata yang diperoleh siswa pada saat setelah menggunakan model Novick (posttest) yakni 83,61 yang termasuk dalam kategori baik. 
Berdasarkan simpulan dapat ditarik beberapa saran sebagai berikut, 1.) Pembelajaran menulis teks drama dengan menggunakan model Novick terbukti efektif sehingga model ini dapat menjadi alternatif lain bagi guru dalam melaksanakan pembelajaran menulis teks drama di sekolah. 2) Agar tercapainya tujuan pembelajaran, seorang guru seharusnya lebih aktif dan kreatif dalam menggunakan model-model pembelajaran sesuai materi pembelajaran. Hal tersebut diharapkan dapat meningkatkan kualitas dan kereativitas siswa dalam kegiatan proses pembelajaran.3) Pada penelitian ini menggunakan desain penelitian one group pretest posttest design. Pada pihak yang ingin melakukan penelitian lebih lanjut mengenai keterampilan menulis teks drama, sebaiknya menggunakan desain penelitian yang berbeda.

\section{DAFTAR PUSTAKA}

Fitriana, Ika Amalia. 2018. Penerapan Model Pembelajaan Novick Untuk Mengembangkan Kemampuan Berpikir Kritis Peserta Didik Pada Materi Kalor Di SMP N 1 Semarang. Jurnal Pendidikan

Kosasih, E. 2017. Ketatabahasaan Dan Kesusastraan. Bandung: Yrama Widya Pratiwi, Yuni \& Frida Siswiyanti. 2014. Teori Drama Dan Pembelajarannya. Yogyakarta: Ombak

Sedarmayanti. 2009. Manajemen Sumber Daya Manusia. Bandung: Bandar Madju

Sugiyono. 2012. Metode Penelitian Bisnis. Bandung: Alfabeta

Sulaiman, N. 2012. Efektivitas Model Pembelajaran Novick Dalam Pembelajaran Kimia Kelas XII IA 2 SMA N 1 Donri-Donri. Jurnal Chemica. Volume [13] : 6773

Tarigan, Henry Guntur. 2008. Menulis Sebagai Suatu Keterampilan Berbahasa. Bandung: Angkasa.

Wijaya, Petrus Danang Mustika. 2016. Peningkatan Kemampuan Menulis Naskah Drama Menggunakan Media Video Klip Pada Sisiwa Kelas XI IPA 2 SMA N 1 Prambanan Klaten Tahun Ajaran 2015/2016. Skripsi. Yogyakarta: Universitas Sanata Dharma. 